\title{
Conditions for shallow geothermal energy utilization in Dinaric karst terrains in Croatia
}

\author{
Staša Borović 1 (10 · Josip Terzić ${ }^{1} \cdot$ Kosta Urumović $^{1}$
}

Received: 29 September 2018 / Accepted: 16 February 2019 / Published online: 2 April 2019

(c) The Author(s) 2019

\begin{abstract}
Hydrogeological and thermogeological properties of the shallow subsurface in the Dinaric karst area of Croatia were investigated in the context of its utilization for ground- and water-source heat pumps (GSHPs and WSHPs). The research encompassed four $100 \mathrm{~m}$ deep boreholes with GSHP installations in both coastal and inland Dinaric karst (different limestones and evaporitic rocks at one location), and a set of six exploratory boreholes, abstraction and reinjection wells for WSHP heating and cooling using seawater on the coast (fractured and karstified limestones). It was determined that rock thermal conductivities are favourable for GSHP utilization, but dependent on the wider rock mass characteristics which are hard to predict (size of karst voids and their saturation status). In addition, wells with high enough yield and stabile seawater or groundwater temperatures for WSHP utilization can be designed in appropriate structural settings (tensional fractures and fracture set intersections). Advantages and disadvantages of the utilized methodology have been pointed out, as well as methods which should prove useful in the future, especially if larger systems are planned. Hydrogeological, geotechnical, and thermal risks expected during the drilling, installation, and operational phases have also been identified. Presented case studies have given the insight into heat pump installation options and conditions in Croatian part of the Dinarides, but can be useful to other researchers and engineers both in the Dinarides and in similar karst regions.
\end{abstract}

Keywords Dinaric karst $\cdot$ Rock thermal properties $\cdot$ Hydrogeological properties $\cdot$ Heat pumps $\cdot$ Croatia

\section{Introduction}

Ground- and water-source heat pumps with high seasonal performance factors are considered as renewable resource heating and cooling devices by the EU (2009/28/EC) and their application is steadily increasing. Heat pumps coupled to closed-loop borehole heat exchangers have been widely utilized and investigated both theoretically and experimentally in the past few decades. Theoretical models following Fourier's law of heat conduction are based on the assumption of a homogeneous and isotropic ground (Carslaw and Jaeger 1959; Ingersoll and Plass 1948), which generally does

This article is a part of a Topical Collection in Environmental Earth Sciences on Sustainable Management of Karst Natural Resources, guest edited by Drs. Sasa Malinovic and Zoran Stevanovic.

Staša Borović

sborovic@hgi-cgs.hr

1 Croatian Geological Survey, Milana Sachsa 2, 10000 Zagreb, Croatia not correspond to real geological conditions in the subsurface, especially in karstified terrains. Long-term (years and decades) performance of GSHP system is highly dependent on the balance between heat extraction during the heating period and heat injection into the surrounding ground during the cooling period. This balance depends on the climate of the region, ground thermal properties, and heat advection by groundwater flow, which is why it is necessary to investigate the potential sites in the local scale. An EU funded GeoMapping project was conducted in 2013-2015 at eight geologically diverse locations throughout Croatia (Fig. 1) to determine the geological conditions for their utilization (Borović et al. 2015).

Four of the studied locations were situated in karst terrains (two on the Adriatic coast-Poreč and Zadar, and two in the hinterland-Gospić and Knin).

WSHPs are thermodynamically more efficient than GSHPs, which is a consequence of more efficient heat transfer by advection, in comparison with conduction (Banks 2008). Although the most common targets of hydrogeological research are fresh water aquifers, in the case of heat 


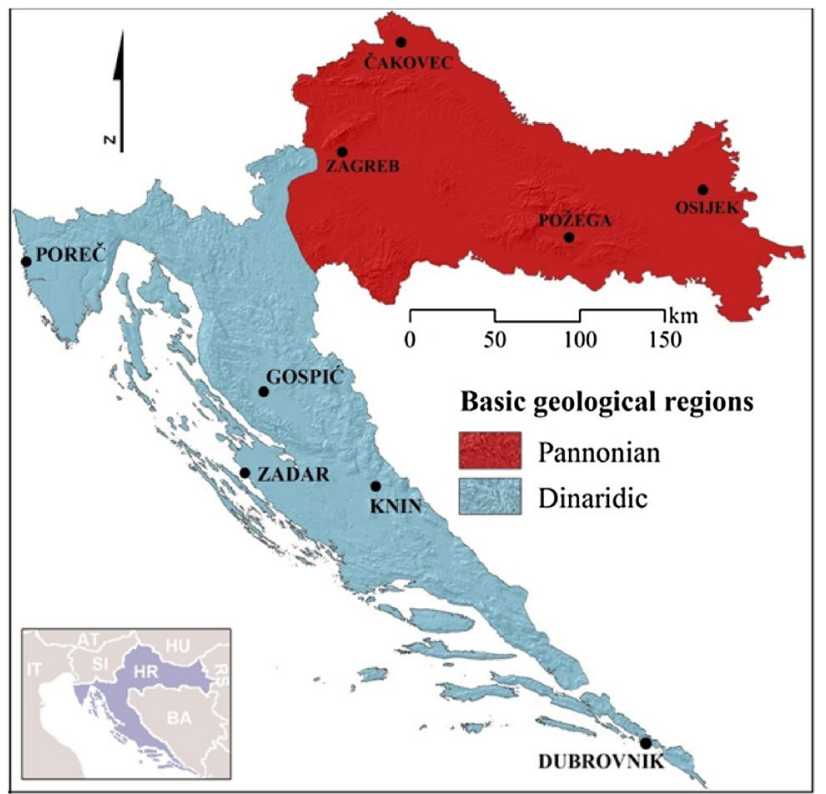

Fig. 1 Locations of presented boreholes

pumps, it is only important to identify structural features with a potential to grant satisfactory yield (which will predominantly be seawater in the karstified coastal zones). Example of such methodology is presented in a case study of structural and hydrogeological research for a WSHP system in Dubrovnik.

During the course of these projects a variety of natural and engineering conditions were encountered, the experiences from which can be useful for development of shallow geothermal energy utilization projects in similar coastal and inland karst environments known for heterogeneity and anisotropy of engineering, hydrogeological, and thermal parameters.

\section{Geological settings}

The so-called karstic Dinarides cover approximately half of Croatian territory (Fig. 1). Their genesis is connected with convergent movement of African plate toward Eurasia (Velić and Vlahović 2009). The contraction of space caused breaking and separation of plate's parts and one of the created microplates was the Adriatic Dinaric Carbonate Platform (ADCP) (Vlahović et al. 2005), which existed until the end of Cretaceous, and its sediments make up the majority of rocks in the Dinarides. Until late Cretaceous, there were several tectonic phases which created the framework for worldwide known locus typicus of karst morphology-the Dinaric karst. The Dinaric karst terrain is characterized by very deep and irregular karstification, predisposed by tectonics. The most common strike of geological structures and main faults (predominantly reverse ones) in karstic Dinarides is NW-SE (the so-called Dinaric strike). Due to the change of tectonic stress direction (Prelogović et al. 2003) in the neotectonic phase (from NE-SW to approximately $\mathrm{N}-\mathrm{S}$ ), old faults were reactivated and new ones occurred. Some faults changed their movement direction, usually from vertical reverse to prevailing horizontal component. Strike of main geological structures remained NW-SE, but in some parts, structures were rotated according to neotectonic pressure and have W-E strike (the so-called Hvar strike). These (mostly carbonate) rocks were subjected to significant faulting and fracturing, which allowed rainwater and surface water infiltration, and of course, their karstification (Garašić and Terzić 2009). The rainwater infiltration is much higher than in non-karstic terrains, and it reaches very deep horizons in some areas. It can hardly be estimated using empirical formulae. Surface drainage network is quite poor, while most of the water flow takes place in the underground. This groundwater flow is determined by local porosity, which is in general estimated to be 3-5\% in karstified limestones, while it is usually much lower in dolomitic rocks (Milanović 2004; Stevanović et al. 2010). One of the most important features is preferential flow paths, which are often connected with important fault zones, where the rock mass is much more fractured and karstified, as well as through some speleological object: caves, pits, and caverns. Still, most of the groundwater accumulation and flow happens within the rock mass in rather tight spaces, the discontinuities within the rock mass. It is also important to point out the significance of epikarst zone, relatively shallow karst weathering zone which significantly increases infiltration locally and contains an important proportion of the groundwater flow (hanging aquifers) until this shallow groundwater infiltrates in deeper karst aquifers. Determination of epikarst zone (especially if there is groundwater flow through it) is very important for placing heat pumps in some areas of the Dinaric karst. Groundwater and karstification are highly interrelated (LaFleur 1999), water dissolves carbonate rocks thus creating numerous cavities and geomorphologic forms, and karst rocks create a completely new environment for infiltration, accumulation, and flow of the groundwater. The main properties of karst aquifers are: (1) in regional and subregional scale karst aquifers can be considered as unconfined and (2) because of spatially varying karstification intensities and depths, the Dinaric karst terrains are extremely heterogeneous. It is practically not possible to use conventional hydrogeological numerical models in the researches of the Dinaric karst, especially in regional and subregional scale, while some parameters can be obtained and estimated in local studies, e.g., around a well, where parameters such as hydraulic conductivity or transmissivity can be calculated, but in further considerations, the values should be taken only as an order of magnitude (Terzić et al. 2007; White 2002). 
It is also important to point out, especially for coastal areas, that karstification in the Dinaric karst is much deeper than it would be expected with regard to present sea level. The mean sea level was over $100 \mathrm{~m}$ lower than today at the end of the last glacial maximum (Würm) about 25,000 years ago, thus making the base of karstification lower as well (Benac and Juračić 1998; Masse and Montaggioni 2001; Šegota 1982). Similar changes in sea level have been verified by newer isotope dating on stalactites from submerged speleological objects (Surić 2006). For the last 6000 years, the trend has stabilized (Benac et al. 2004; Pirazzoli 2005). Some 15,000 years ago, sea level was about $70 \mathrm{~m}$ lower then today. Obviously, the karstification base was still much lower than at present. Most of thus created coastal karst siphons are now submerged by the sea. When groundwater pressure from the hinterland is high enough, submarine karst siphons function as submarine springs (vruljas), but never too far from the coast. When groundwater pressure drops, the seawater penetrates karst aquifers causing salinization in wedge-like form (Urumović 2000). Shape and depth of this wedge are far from regular because of the described karstic inhomogeneity and anisotropy.

\section{Materials and methods}

Although the Dinaric karst is different from other karstic areas in the world, most of the research methods used in karst hydrogeology (Bakalowicz 2005; Ford and Williams 2007; Milanović et al. 2014; White 2002) can be applied, sometimes adjusted to environment.

\section{Closed-loop/ground-source heat pump cases}

In the scope of GeoMapping project, it was important to choose locations with different limestone rock masses: compact limestones and heavily karstified limestones (e.g., Poreč vs. Zadar). Another goal was to balance localities at the seaside and in the hinterland, due to different climate and groundwater flow patterns (e.g., Gospić vs. Zadar) (Fig. 1).

Core drilling was performed until $100 \mathrm{~m}$ at all locations, followed by detailed geological and hydrogeological borehole core determination and sampling. The described borehole geology was determined on the basis of relevant sheets of the Basic geological maps, following their chronostratigraphic approach.

Double U-pipe heat exchangers were installed into the boreholes, with optical fibre cable for distributed temperature measurements inside them. Boreholes were then grouted using thermally enhanced grout (GeoSolid 235 by Fischer, $\lambda=2.35 \mathrm{Wm}^{-1} \mathrm{~K}^{-1}$ ). Thermal parameters, which are crucial in determining systems' efficiency, were measured both in natural and laboratory scale. In natural scale, the thermal response test (TRT) and distributed TRT (DTRT)—using advanced distributed temperature sensing by fibre optic cables-were conducted. The results of thermal response testing have been published in a previous paper (Soldo et al. 2016). Direct measurements on core samples were conducted by ISOMET 2114 equipment, using predominantly surface probe (for rocks), but also the needle probe for partially solidified samples. All samples were prepared as required by the manufacturer and conformed to the proscribed dimensions (AppliedPrecision 2013). More details on measurement technique itself can be found in (Kušnerová et al. 2013; Prelovšek and Uran 1984; Uran 1982).

\section{Open-loop/groundwater heat pump case}

Wells were drilled on the site of a future hotel to ensure supply of seawater for a heat pump system. Due to limited land area owned by the investor, the research aimed at finding significant fracture systems which can support the required production and reinjection rates.

Hydrogeological survey was conducted in three stages: (1) detailed hydrogeological mapping of the area with proposals for locations of exploratory boreholes; (2) based on borehole core mapping and pumping tests, locations of exploitation and injection wells were determined; and (3) hydrogeological parameters were determined from pumping test data analyses of all wells (Z-1, Z-2, Z-3, Z-4). Pumping tests were conducted, as shown in Table 1: $3 \times 1 \mathrm{~h}$ step test and $8 \mathrm{~h}$ constant test $(Q=60 \mathrm{l} / \mathrm{s})$.

Identification of well losses was calculated using the Rorabaugh (1953) method:

$s=B Q+C Q^{2}$,

where $s$ is drawdown (m), $B$ is formation loss coefficient, $C$ is well loss coefficient, and $Q$ is pumping rate $\left(\mathrm{m}^{3} / \mathrm{s}\right)$.

Double check of well parameters (non-linear well losses and effective well radius) was based on Jacob (1947) and Rorabaugh (1953) methods. The method used for parameter estimation is the combination of Rorabaugh (1953) method and Thiem (1906) equation of steady radial flow (Urumović et al. 2013). These equations can be combined as a function of specific drawdown:

$\frac{s_{\mathrm{z}, \mathrm{tn}}-C Q_{\mathrm{tn}}^{2}-s_{\mathrm{p}, \mathrm{tn}}}{Q_{\mathrm{tn}}}=C_{\mathrm{s} / \mathrm{Q}}=\frac{1}{2 \pi T} \ln \frac{r_{\mathrm{p}}}{r_{\mathrm{z}}}=\mathrm{const}$,
Table 1 Pumping quantities during step tests and constant test

\begin{tabular}{llll}
\hline Well & $Q_{1}(1 / \mathrm{s})$ & $Q_{2}(1 / \mathrm{s})$ & $Q_{3}(1 / \mathrm{s})$ \\
\hline $\mathrm{Z}-1$ & 6 & 21 & 60 \\
$\mathrm{Z}-2$ & 6 & 30 & 60 \\
$\mathrm{Z}-3$ & 6 & 20 & 60 \\
$\mathrm{Z}-4$ & 6 & 20 & 60 \\
\hline
\end{tabular}


where $C\left(\mathrm{~s}^{2} / \mathrm{m}^{5}\right)$ is parameter of non-linear well losses, $C_{\mathrm{s} / \mathrm{Q}}$ $\left(\mathrm{s} / \mathrm{m}^{2}\right)$ is specific drawdown coefficient, $Q_{\mathrm{tn}}\left(\mathrm{m}^{3} / \mathrm{s}\right)$ is pumping rate in moment $t_{\mathrm{n}}, T\left(\mathrm{~m}^{2} / \mathrm{s}\right)$ is transmissivity of an aquifer, $r_{\mathrm{z}}(\mathrm{m})$ is effective diameter of pumped well, $r_{\mathrm{p}}(\mathrm{m})$ is radial distance between pumped well and the observation borehole, $s_{z, t \mathrm{n}}(\mathrm{m})$ is drawdown in pumped well in moment $t_{\mathrm{n}}, s_{\mathrm{p}, \mathrm{tn}}(\mathrm{m})$ is drawdown in observation borehole in moment $t_{\mathrm{n},}$ and $t_{\mathrm{n}}(\mathrm{min})$ is time increment in pumping test.

In the cases considered, the most suitable method for aquifer parameters calculation was that of well hydraulic parameter calculation with the successive series of stationary states. During the pumping quantity $Q$, the radial flow of the groundwater toward the well appears and the parameters are determined as

$s=\frac{Q}{2 \pi T} \ln \frac{R_{0}}{r_{\mathrm{z}}}$,

where $s(\mathrm{~m})$ is the equivalent drawdown, $Q(1 / \mathrm{s})$ is the pumping rate, $T\left(\mathrm{~m}^{2} / \mathrm{s}\right)$ is the transmissivity, $R_{0}(\mathrm{~m})$ is the fictive radius of the well influence, and $r_{\mathrm{z}}(\mathrm{m})$ is the effective radius of the well.

For purpose of result verification, Cooper and Jacob (1946) method was used. This method is usually used for identification of hydrogeological parameters of intergranular aquifers, but can also be used for parameter estimation in fractured rock aquifers. Based on depression cone data as a function of time, transmissivity can be determined from relation:

$s=\frac{2.3 Q}{4 \pi T} \log \frac{2.25 T t}{r^{2} s}$

and storage coefficient can be estimated from

$S=\frac{2.25 T t_{0}}{R_{\mathrm{p}}^{2}}$ where $s(\mathrm{~m})$ is the equivalent drawdown, $Q(1 / \mathrm{s})$ is the pumping rate, $T\left(\mathrm{~m}^{2} / \mathrm{s}\right)$ is the transmissivity, $t_{0}(\mathrm{~min})$ is the intercept of the line on the $x$-axis, and $R_{\mathrm{p}}(\mathrm{m})$ is the radial distance from pumping well to observation well.

\section{Results and discussion}

\section{Closed-loop/ground-source heat pump cases}

The boreholes in Poreč, Gospić, and Zadar are located in carbonate rocks (limestones), while in the borehole in Knin, mostly evaporitic rocks were present (gypsum and anhydrite in different proportions). In such different geological environments, thermal properties of the subsurface were correspondingly disparate.

The Zadar borehole was completely situated in limestones, upper $80 \mathrm{~m}$ in foraminiferal Paleogene limestone, and lower $20 \mathrm{~m}$ in Upper Cretaceous (Majcen and Korolija 1967). The boundary between the two is transgressive. There are some lithological differences, but hydrogeologically, they behave very similar. Both are fractured and karstified, while foraminiferal limestones were estimated to be slightly less permeable. Within the borehole, several cavern zones have also been drilled and strong groundwater flow was noted, especially after heavy rains (Fig. 2).

The Gospić borehole, after $4 \mathrm{~m}$ of fine-grained Quaternary deposits, entered into so-called Jelar breccias (Sokač et al. 1967) (Fig. 3). These are limestone breccias of Eocene-Oligocene age. Their hydrogeological behavior is similar to Cretaceous limestones, but they are, in general, characterized by lower permeability. There were no significant caverns, karstification level was mediocre, and most of the groundwater flow happens through discontinuities within the rock mass.

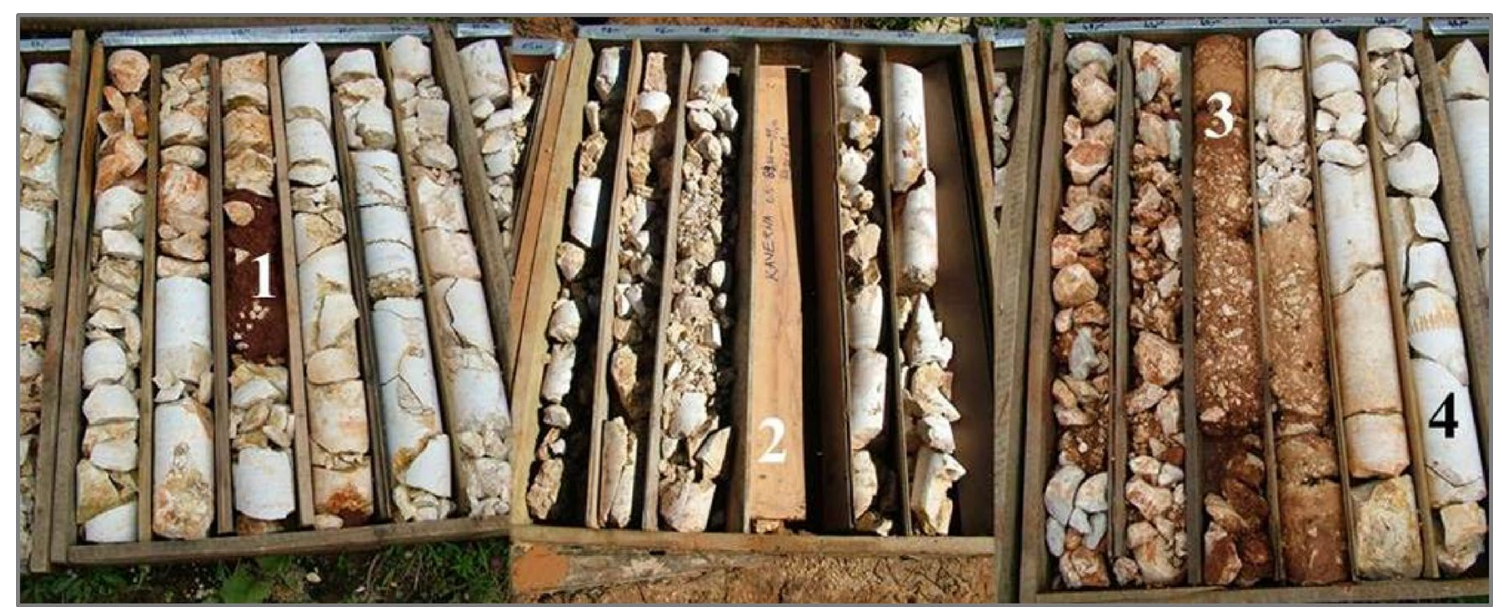

Fig. 2 Different materials in the rock mass of Zadar borehole: (1) terra rossa; (2) cavern; (3) rock fragments and terra rossa-partially solidified; (4) fractured rock 

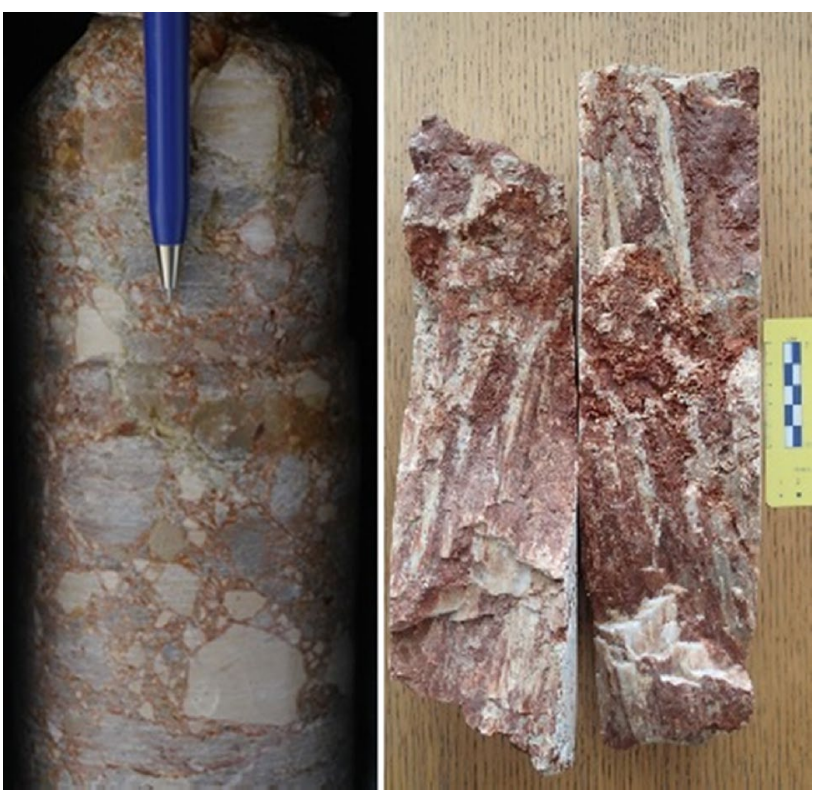

Fig. 3 Compact Jelar breccia (left) and a fracture with striations (right)

The Poreč borehole was located in the core of the Western Istrian Jurassic-Cretaceous anticline (Polšak and Šikić 1963). Whole borehole was drilled through Upper Jurassic limestones (Kimmeridgian-Tithonian). Although the rock mass is composed of limestones, it was not very karstified, and no caverns have been detected. Fracturing was high, so most of the groundwater flow happens within the rock mass itself.

The Knin borehole was quite a special case because of the diapiric phenomenon in Knin polje (Dedić et al. 2018; Grimani et al. 1966; Kulušić and Borojević Šoštarić 2014). Up to $40 \mathrm{~m}$ depth, the borehole was drilled through Quaternary deposits, mostly terra rossa in the first meter, followed by thick diluvial deposits. Last $60 \mathrm{~m}$ were completely in Permian-Triassic evaporitic rocks: gypsum and anhydrite mixture (Fig. 4). These rocks were not karstified, as they were not subject to weathering or corrosion, which would cause very quick dissolution. Their thermal properties are also quite different than that of carbonates which prevail throughout the Dinaric karst.

Table 2 shows the measurement results for typical carbonate and evaporitic rocks of the Croatian Dinaric karst. It is known that the matrix porosity in carbonate and evaporitic rocks is very low, i.e., negligible in an engineering sense. Therefore, their thermal properties are mostly dictated by the thermal properties of minerals constituting the rock matrix, the fracture and/or karst porosity, and the fluid which fills in fractures and caverns. In such medium, it is very significant which fluid fills in the voids, because air has roughly 30 times lower thermal conductivity than water, which in turn

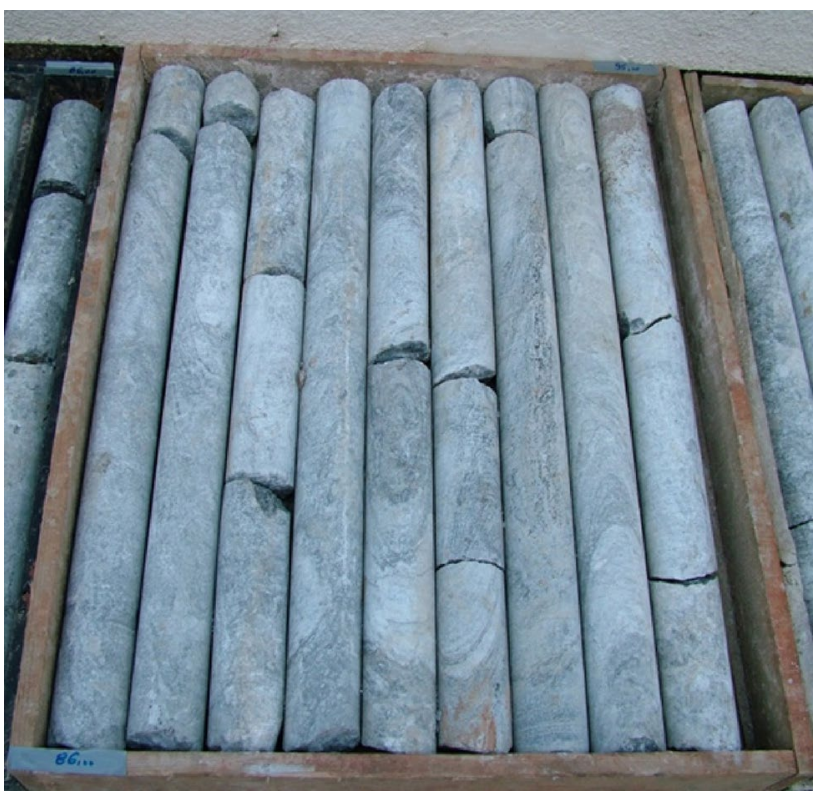

Fig. 4 Evaporitic rocks in Knin borehole

has tenfold lower thermal conductivity than rock forming minerals, e.g., $\lambda_{\text {air }} \approx 0.02 \mathrm{Wm}^{-1} \mathrm{~K}^{-1}, \lambda_{\text {water }} \approx 0.6 \mathrm{Wm}^{-1} \mathrm{~K}^{-1}$, $\lambda_{\text {minerals }} \approx 1-7 \mathrm{Wm}^{-1} \mathrm{~K}^{-1}$.

It is visible that different rocks of limestone (calcite) composition have quite similar thermal conductivities in laboratory scale (Table 2). In addition, measured rock thermal conductivities are generally lower than that of pure mineral calcite, although the rocks are composed of up to $98 \%$ calcite (Majcen and Korolija 1967; Polšak and Šikić 1963; Sokač et al. 1967). Unlike rock (and especially rock mass) thermal conductivities, those of pure minerals have been precisely determined. At standard temperature, thermal conductivity of calcite is in the range of $3.3-3.6 \mathrm{Wm}^{-1} \mathrm{~K}^{-1}$ (Robertson 1988) or 3.3-3.8 $\mathrm{Wm}^{-1} \mathrm{~K}^{-1}$ (Momenzadeh et al. 2018) depending on the orientation of crystals in relation to heat flow.

In Fig. 2, it is important to notice that caverns are present, which, depending on the groundwater levels, can be filled by

Table 2 Average thermal conductivities of rock samples in $\mathrm{Wm}^{-1} \mathrm{~K}^{-1}$

\begin{tabular}{llllll}
\hline & Gospić & Knin & Poreč & Zadar & Average \\
\hline $\begin{array}{l}\text { Foraminiferal } \\
\text { limestone }\end{array}$ & & & & $2.73(8)$ & 2.73 \\
$\begin{array}{l}\text { Cretaceous lime- } \\
\text { stone }\end{array}$ & & & $2.18(4)$ & $3.28(4)$ & 2.73 \\
Jelar breccia & $2.95(6)$ & & & & \\
Gypsum/anhydrite & & $3.01(17)$ & & 2.90 \\
\hline
\end{tabular}

Ten measurements per sample were conducted (number of samples in parentheses) 
water or air-causing different heat transfer environments. Groundwater flow means an increase in heat transfer by convection, which is added to conductive transfer, leading to an overall positive effect (higher total heat transfer). However, if the voids are filled by the air, it is a very unfavourable situation, since the air is known to be thermal insulator. In addition, terra rossa and rock fragments with terra rossa can be present. All of these deposits cause lower thermal conductivity in natural scale in comparison with laboratory scale, since thermal conductivity of such mixtures was determined at different localities to be around only $1 \mathrm{Wm}^{-1} \mathrm{~K}^{-1}$.

In Gospić, the situation was much simpler, since out of the $100 \mathrm{~m}$ which were core-drilled, $97 \mathrm{~m}$ were, in engineering sense, uniform Jelar breccia (clast-supported, unsorted, mostly monomictic limestone breccia with miciritic, mostly reddish matrix), intersected by a few more significant fractures (possibly faults) (Fig. 3). In such an environment (similar to the Poreč borehole), when the fractures are minor and the limestones are generally undisturbed, thermal properties are more consistent and depend on the thermal properties of rock forming mineral.

The measured thermal conductivity data for limestones in Croatian part of Dinaric karst are very similar to values reported in the most known standard collections for heat pump utilization, those from Germany (VDI 2001) and Switzerland (SIA 2010), which report $2.7 \mathrm{Wm}^{-1} \mathrm{~K}^{-1}$ and $2.8 \mathrm{Wm}^{-1} \mathrm{~K}^{-1}$, respectively. Considering very different conditions and events that the limestones have endured in the Dinarides compared to the Alpine foreland Molasse basin of Germany and Switzerland, a more significant discrepancy was expected.

The evaporitic rock mass consisting of gypsum and anhydrite is very interesting, because according to Robertson (1988), thermal conductivity of gypsum is $1.2 \mathrm{Wm}^{-1} \mathrm{~K}^{-1}$ and of anhydrite $6.0 \mathrm{Wm}^{-1} \mathrm{~K}^{-1}$. This difference is caused by the fact that gypsum absorbs water molecules into its crystal lattice $\left(\mathrm{CaSO}_{4} \cdot 2 \mathrm{H}_{2} \mathrm{O}\right)$, which, therefore, has much lower density in comparison with anhydrite lattice $\left(\mathrm{CaSO}_{4}\right)$. According to contemporary phonon heat conduction theory, higher density is a physical cause of higher thermal conductivity (Beardsmore and Cull 2001). Although it was not possible to determine the proportions of gypsum and anhydrite in the rock samples from Knin by optical methods standard in mineralogical and petrographic research, different proportions of the two components could be assumed on the basis of very variable thermal conductivities. 17 rock samples were collected from a $60 \mathrm{~m}$ sequence of evaporitic rocks and thermal conductivities were measured in a range of $1.63-5.16 \mathrm{Wm}^{-1} \mathrm{~K}^{-1}$.

In an environment with significant freshwater flow from the hinterland, its impact cannot be overstated, which was specifically proven by thermal recovery measurements after distributed thermal response testing in Zadar. It is clear that in such places, thermal recovery is rapid in comparison with other areas, where groundwater flow is lower, which is visible from much higher thermal conductivity measured by DTRT in comparison with laboratory measurements on samples (Table 3). This occurs, because TRT device can only measure total heat transfer via temperature differential, while in cases of strong groundwater flow, the heat is transferred by convection as well. However, in the subsequent calculations, all heat transfers are attributed to conduction, thereby unrealistically increasing thermal conductivity of the medium. In this specific case, a combination of karst environment and strong groundwater flow through the karst conduits or preferential flow paths following a storm event also caused significant drilling equipment drop-downs and blockades, which finally resulted in abandonment of the borehole and its relocation.

\section{Open-loop/water-source heat pump case}

At the location of a future hotel in Dubrovnik (Fig. 1), boreholes were favoured to surface intake due to aesthetic requirements, but also as a solution which offers higher energy efficiency. Predicted drilling area for the boreholes was only $400 \mathrm{~m}^{2}$ for 2 observation wells, 2 production, and 2 reinjection wells (Fig. 5).

The goal was to identify preferential flow paths in tectonically disturbed limestone rock mass composed of reef limestones of Upper Cretaceous age (Marković 1966) (Fig. 6). Since the research area is situated in a small peninsula, there is practically no fresh groundwater and seawater penetration into this highly permeable karst aquifer is total. Only during rainy season, the groundwater becomes slightly brackish for a short time period. The initial hydrogeological prospection was conducted by mapping the structural elements and determining the positions of tension and dissolution fractures in the rock mass, which were considered to be the most promising structural element, able to ensure high enough yield and good reinjection properties of the future wells (Urumović et al. 2016). In the first phase of investigations, three locations were selected as the most promising. In the second phase of investigations, based on a survey of nearby

Table 3 Results of subsurface thermal conductivity determination in $\mathrm{Wm}^{-1} \mathrm{~K}^{-1}$ along the borehole length

\begin{tabular}{lllc}
\hline & \multicolumn{2}{l}{ Measurement technique } & Discrepancy (\%) \\
\cline { 2 - 3 } & LAB & DTRT & LAB-DTRT \\
\hline Gospić & 2.92 & 2.73 & 6.96 \\
Knin & 2.58 & 2.08 & 24.04 \\
Poreč & 2.19 & 2.05 & 6.83 \\
Zadar & 2.86 & 3.21 & -10.9 \\
\hline
\end{tabular}

DTRT results from (Soldo et al. 2016) 


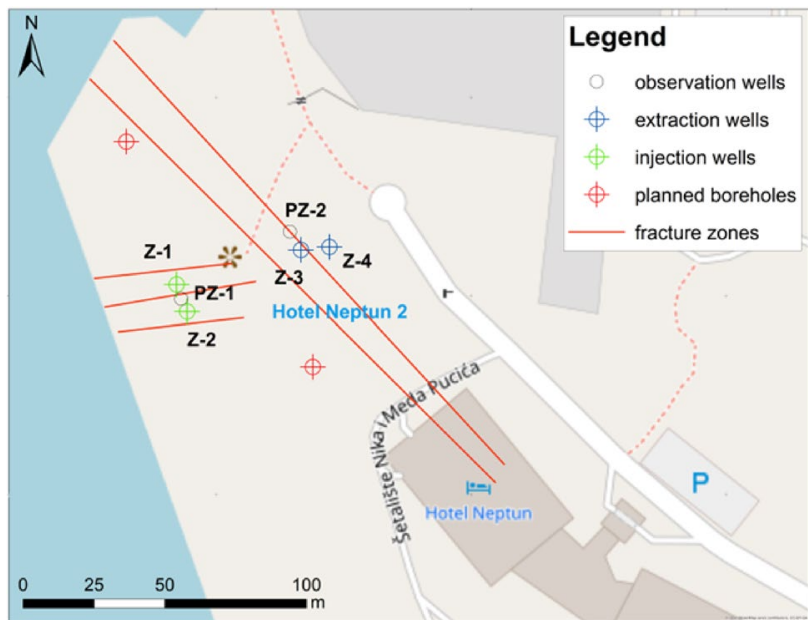

Fig. 5 Locations of observation, production, and reinjection wells

construction pit, new locations of exploratory boreholes and wells were selected (Fig. 5).

Abstraction wells are 30 and $40 \mathrm{~m}$ deep and both reinjection wells are $25 \mathrm{~m}$ deep. The depths of abstraction wells were increased in comparison with initial plan, to minimize the temperature variations of seawater. This approach resulted in a very favourable regime between two production and two reinjection wells. Results of step test analyses are presented in Table 4.

The required seawater intake for the system was $50 \mathrm{l} / \mathrm{s}$. According to well parameter calculations according to Eqs. (1) and (2), over 500 l/s could be ensured (last column of Table 4). Pumping test was conducted with $Q_{\max }=50 \mathrm{l} / \mathrm{s}$ and drawdowns in the abstraction wells were negligible $(10-30 \mathrm{~cm})$, varying in concordance with tidal cycle (exemplified by well Z3 in Fig. 7). Owing to an excellent yield of the abstraction wells and total reinjection, heating and cooling for both buildings (Hotels Neptun and Neptun 2, Fig. 5) of the establishment are now supplied by the system originally planned for only one-smaller-building.

The analysis combining Rorabaugh and Thiem formulae confirmed calculated values of coefficient $C$.

For the purpose of determining hydrogeological parameters, all the data were used, and the graphoanalytical solution for well is exemplified for Z-4 pumping test in Fig. 8.

The value of storage coefficient $S=42.8$ is not considered realistic, due to short radial distance from pumping well to observation well.
Fig. 6 Locations of boreholes in Dubrovnik (red circle) on the geological map according to (Marković 1966)

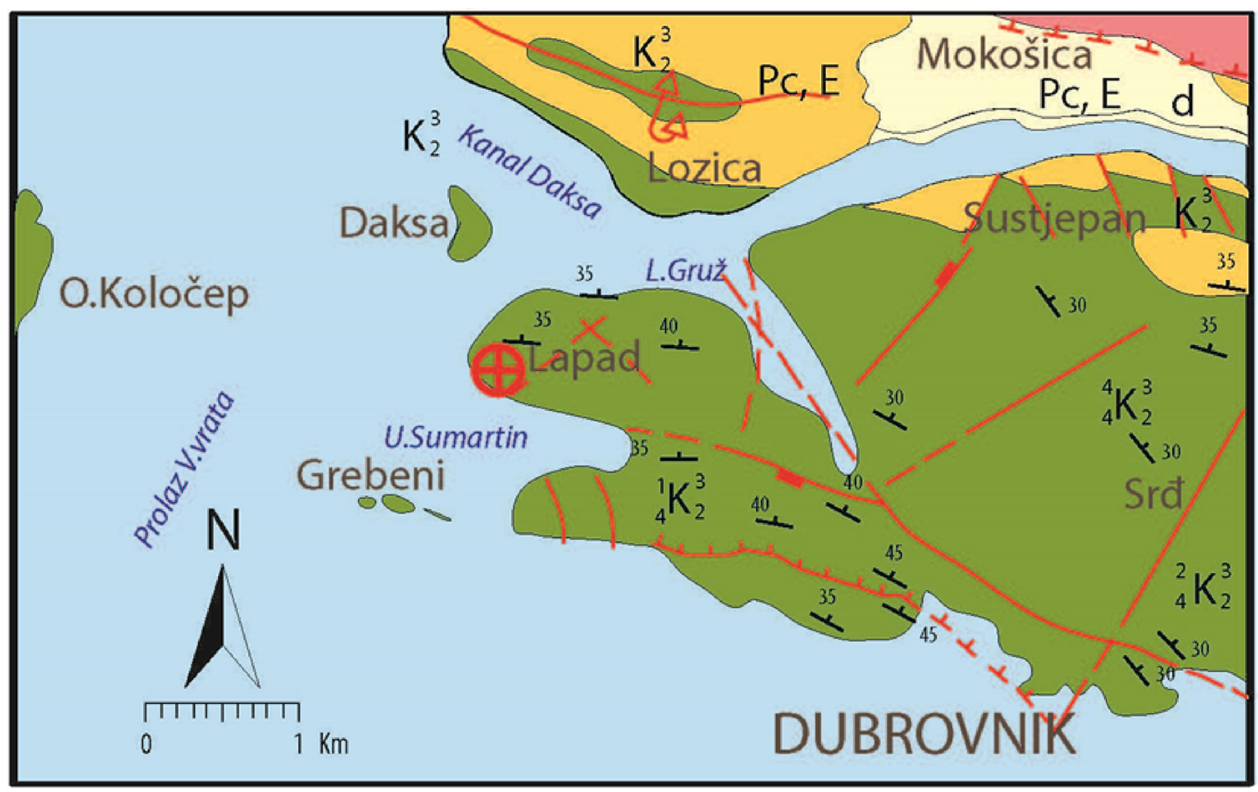

\begin{tabular}{lllll}
\hline Well & $B$ & $C$ & $\begin{array}{l}\text { Calculated drawdown with pump- } \\
\text { ing rate } Q=50 \mathrm{l} / \mathrm{s}(\mathrm{m})\end{array}$ & $\begin{array}{l}\text { Calculated well } \\
\text { capacity with } s=2 \mathrm{~m} \\
(1 / \mathrm{s})\end{array}$ \\
\hline Z-1 & 4.10 & 42.74 & 0.30 & 173 \\
Z-2 & 2.00 & 5.56 & 0.13 & 420 \\
Z-3 & 1.25 & 12.50 & 0.10 & 350 \\
Z-4 & 3.63 & 43.75 & 0.29 & 175 \\
\hline
\end{tabular}

Table 4 Well losses for wells Z-1, Z-2, Z-3, and Z-4 


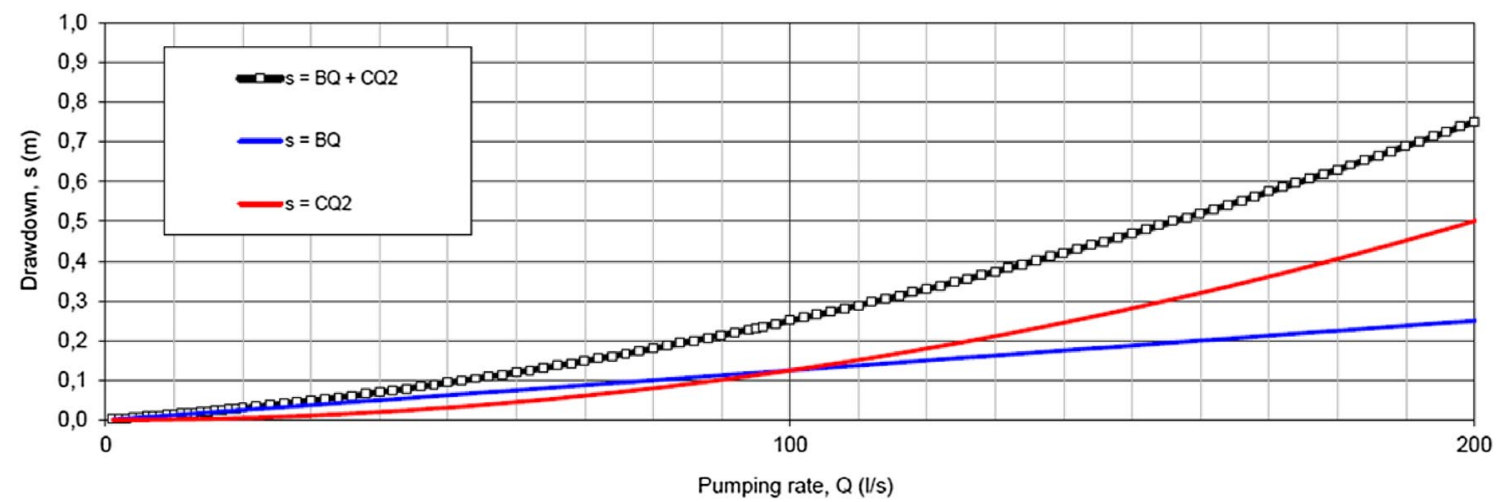

Fig. 7 Analyzed step test data for Z-3

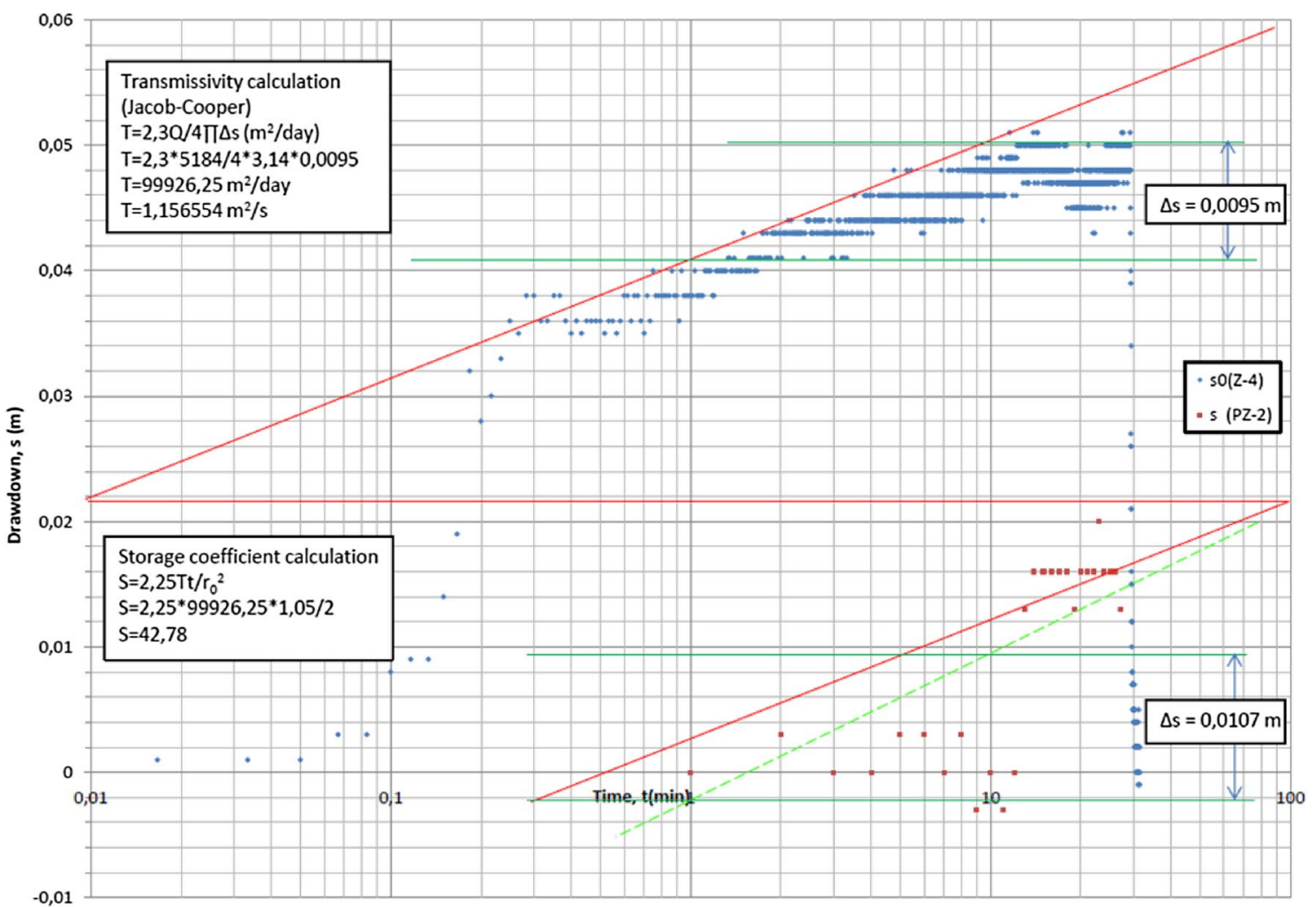

Fig. 8 Z-4 well pumping test data analyzed using Cooper and Jacob (1946) method

Results of aquifer transmissivity calculation according to Eqs. (3), (4), and (5) are presented in Table 5.

Water temperature record showed that high hydraulic connection is established with the sea and groundwater from the inland (also saline). Since the pump has rather high impact on water temperature, the temperature was monitored in the observation boreholes instead of wells. In the time of the pumping, sea temperature was $14^{\circ} \mathrm{C}$, and saline groundwater temperature was $18{ }^{\circ} \mathrm{C}$. Temperature monitoring data also indicated that well doublets have intersected different sets of discontinuities, since the temperature trends differed.
Table 5 Aquifer transmissivity

Method

Average transmissivity for all wells $\left(\mathrm{m}^{2} / \mathrm{s}\right)$

Thiem (1906) 0.90

Cooper and Jacob (1946) 
In observation well PZ1, located closer to the sea, monitoring data showed variation of temperature $\left(17.09-17.76{ }^{\circ} \mathrm{C}\right)$, while in borehole PZ-2, located farther inland showed temperature stagnation at $17.09{ }^{\circ} \mathrm{C}$.

\section{Conclusions}

Shallow subsurface of the Dinaric karst area, which makes up roughly a half of Croatian territory, was investigated to determine the conditions for GSHP and WSHP utilization, and the results were encouraging for the deployment of both types of systems. Concerning GSHPs, the collected data show that laboratory measurements systematically overestimated ground thermal conductivity in karst terrains in general, but underestimated it in the areas of high groundwater flow from the hinterland through karst conduits, i.e., thermal properties of rock mass do not correspond well to thermal properties of carbonate rock as a monolith. DTRT has proven to be an excellent indicator of natural scale thermal properties of karstified rock mass and, additionally, of karst phenomena such as highly karstified fault and fracture zones-preferential paths of groundwater flow, where heat is transferred by advection, not only by conduction in the solid matter (Soldo et al. 2016). In addition, the unpredictability of drilling and heat exchanger installation in karst terrain was confirmed, and attributed to subsurface geological properties. Considering WSHPs in the coastal area, it was proven that by detailed hydrogeological and structural research, wells with high yields, total reinjection and stabile water temperature can be constructed. Although seawater pumped from the karst aquifer will certainly experience some seasonal temperature variations, it will be far less pronounced than it would be the case using direct intake from the sea. The boreholes further from the shoreline should generally be used for abstraction to minimize seasonal temperature variation caused by insolation. Such layout can increase the seasonal performance factor of the entire heat pump system throughout its operational lifetime.

There are risks involved both during drilling and operational phases. During the drilling, tools blockade and/ or drop-down in the borehole have to be foreseen. Strong groundwater flows can amplify these problems, especially if storm events are forecasted in the hinterland. For practical purposes, most of such boreholes would not be coredrilled, which would diminish related karst problems. If more boreholes or wells were planned, surface geophysical researches typically used in engineering in karst should be foreseen. Seismic refraction profiling would be advisable, to distinguish between rock and weathered/epikarst zone, to reduce the drilling risks caused by equipment drop-downs and blockades. Electrical resistivity tomography should be conducted in the case of drilling for WSHPs to identify preferential groundwater flow paths or seawater intrusion paths.

Risks present in the operational phase can be divided into hydrogeological, geotechnical, and thermogeological risk. Hydrogeological risks include water contamination by refrigerants and carrier fluids. Refrigerants in heat pumps are mostly halogenated hydrocarbons and should not enter groundwater (2000/60/EC; 2006/118/EC). Such a development can only be caused by an incident situation, so the risk is considered fairly low. The most common carrier fluids are alcohol and water or salt and water mixtures. The one with the best thermodynamic and fluid dynamic properties is ethylene glycol and water mixture. However, ethylene glycol is highly toxic and should not enter the environment. Other options are constantly being considered and tested (Banks 2008). In this case, the possibility of an incident is higher than leakage of halogenated hydrocarbons, since carrier fluids circulate in the underground. Such leakages should definitely be avoided in karst environment which in known for its negligible autopurification capacity. One of the possible geotechnical risks in karst is the destruction of installed borehole equipment during storm events, in case large caverns are present, since they can become conduits with significant flow velocities and a path for movement of rock fragments. Evaporitic rocks present an even greater danger. Anhydrite which comes into contact with groundwater starts to absorb water molecules into its crystal lattice, which causes a $61 \%$ volumetric increase. This kind of swelling causes pressure which damages all forms of infrastructure as well as the ground uplift of up to $10 \mathrm{~mm} / \mathrm{month}$ (Sass and Burbaum 2010). Obviously, if there are indications that anhydrite rocks could come into contact with groundwater, drilling and installation should be approached with due caution. Thermal pollution can manifest itself through excessive cooling or heating of the subsurface if heat extraction/injection imbalance caused by heat pump system operation cannot be dissipated. Thermogeological risk is present in areas, where a differential in annual heating and cooling loads is significant, and combined with unfavourable thermal parameters and/or low groundwater flow. In the coastal part of Dinaric karst in Croatia, the cooling load is usually higher, meaning that the ground could slowly heat up, thereby decreasing the seasonal performance factor of the system. In the inland part, the situation is opposite and the heating load prevails, so the ground could start cooling down, with the same negative effect. However, due to identified favourable thermal conductivities, as well as significant groundwater flow, such risks are not foreseen as long as a reasonable number of installations are maintained. Thermal short-circuiting is connected to open-loop systems, and represents a situation, where a pumping well extracts water from heated/cooled plume created by an injection well. In case of very favourable hydraulic properties of karstified 
rock mass, as exemplified by Dubrovnik WSHP system, such situation can be avoided by maintaining reasonable pumping rates, as well as by positioning the reinjection wells downgradient from abstraction wells.

Since only a limited number of possible research locations were available, no dolomite or flysch rock masses were tested in the Croatian Dinaric karst area. This should be a topic of future investigations due to their significant presence in the shallow subsurface throughout the Dinaric karst region, as well as because of known differences in their thermal and engineering parameters in comparison with limestone and evaporitic rock masses presented in this paper.

Acknowledgements Presented GSHP data were acquired through EU IPA funded project "Research and the Promotion of the Use of Shallow Geothermal Potential in Croatia", acronym GeoMapping (Grant No. IPA2007/HR/16IPO/001-040506), and WSHP data through a project "Hydrogeological research for wells for heating and cooling of the hotel 'Neptun 2'", funded by Apsida inženjering Ltd, Dubrovnik. The authors wish to thank Ladislav Fuček and Tonći Grgasović for the geological determination of borehole core material.

\section{Compliance with ethical standards}

Conflict of interest The authors declare that they have no conflict of interest.

Open Access This article is distributed under the terms of the Creative Commons Attribution 4.0 International License (http://creativeco mmons.org/licenses/by/4.0/), which permits unrestricted use, distribution, and reproduction in any medium, provided you give appropriate credit to the original author(s) and the source, provide a link to the Creative Commons license, and indicate if changes were made.

\section{References}

2000/60/EC Directive of the European Parliament and of the Council establishing a framework for the Community action in the field of water policy

2006/118/EC Directive of the European Parliament and of the Council of 12 December 2006 on the protection of groundwater against pollution and deterioration

2009/28/EC Directive of the European Parliament and of the Council of 23 April 2009 on the promotion of the use of energy from renewable sources and amending and subsequently repealing Directives 2001/77/EC i 2003/30/EC

AppliedPrecision (2013) ISOMET 2114 Thermal properties analyzer User's Guide Version 011213. Bratislava

Bakalowicz M (2005) Karst groundwater: a challenge for new resources. Hydrogeol J 13:148-160

Banks D (2008) An introduction to thermogeology, 2nd edn. WileyBlackwell, Oxford

Beardsmore GR, Cull JP (2001) Crustal heat flow-a guide to measurement and modelling. Cambridge University Press, Cambridge

Benac Č, Juračić M (1998) Geomorphological indicators of sea level changes during upper Pleistocene (Würm) and Holocene in the Kvarner region (NE Adriatic Sea). Acta Geographica Croatica $33: 27-45$
Benac Č́, Juračić M, Bakran-Petricioli T (2004) Submerged tidal notches in the Rijeka bay, NE Adriatic Sea: indicators of relative sea-level change and of recent tectonic movements. Mar Geol 212:21-33

Borović S, Urumović K, Terzić J (2015) Mapping of the shallow geothermal potential in the Republic of Croatia. Croatian Geological Survey, Zagreb

Carslaw HS, Jaeger JC (1959) Conduction of heat in solids, 2nd edn. Oxford Science Publications, Oxford

Cooper HH, Jacob CE (1946) A generalized graphical method for evaluating formation constants and summarizing well field history. Am Geophys Union Trans 27:526-534

Dedić Ž, Ilijanić N, Miko S (2018) Mineralogical-petrographical study of evaporites from Mali Kukor, Vranjkovići and Slane Stine quarry (Upper Permian evaporites from Dalmatia, Croatia). Geologia Croatica 71:19-28. https://doi.org/10.4154/ gc. 2018.02

Ford DC, Williams P (2007) Karst hydrogeology and geomorphology. Wiley, West Sussex

Garašić M, Terzić J (2009) Karstification, caves and karst aquifers on the Adriatic Islands (Croatia). Paper presented at the European Geosciences Union General Assembly 2009: geophysical research abstracts 11, Vienna, Austria, 19-24 April 2009

Grimani I, Juriša M, Šikić K, Šimunić A (1966) Explanatory notes for basic geological map-sheet Knin. Institute for Geological Research, Zagreb

Ingersoll LR, Plass H (1948) Theory of the ground pipe heat source for the heat pump, ASHRAE Transactions 54

Jacob CE (1947) Drawdown test to determine effective radius of artesian wells. Trans Am Soc Civ Eng 112:1047-1064

Kulušić A, Borojević Šoštarić S (2014) Dinaride evaporite mélange: diagenesis of the Kosovo polje evaporites. Geologia Croatica 67:59-74. https://doi.org/10.4154/gc.2014.05

Kušnerová M et al (2013) A proposal for simplifying the method of evaluation of uncertainties in measurement results. Meas Sci Rev $13: 1-6$

LaFleur RG (1999) Geomorphic aspects of groundwater flow. Hydrogeol J 7:78-93

Majcen Ž, Korolija B (1967) Explanatory notes for the Basic geological map — sheet Zadar. Institute for geological research, Zagreb

Marković B (1966) Basic geological map of the SFRY 1:100.000, Sheet Dubrovnik. Department of geological and geophysical research, Belgrade

Masse JP, Montaggioni LF (2001) Growth history of shallow-water carbonates: control of accommodation on ecological and depositional processes. Int J Earth Sci Geol Rundsch 90:452-469

Milanović PT (2004) Water resources engineering in karst. CRC Press, Boca Raton

Milanović S, Stevanović Z, Vasić L, Ristić-Vakanjac V (2014) 3D modeling and monitoring of karst system as a base for its evaluation and utilization: a case study from eastern. Serbia Environ Earth Sci. https://doi.org/10.1007/s12665-013-2591-9

Momenzadeh L, Moghtaderi B, Buzzi O, Liu X, Sloan SW, Murch GE (2018) The thermal conductivity decomposition of calcite calculated by molecular dynamics simulation. Comput Mater Sci 141:170-179. https://doi.org/10.1016/j.commatsci.2017.09.033

Pirazzoli PA (2005) A review of possible eustatic, isostatic and tectonic contributions in eight late-Holocene relative sea-level histories from the Mediterranean area. Quat Sci Rev 24:1989-2001

Polšak A, ك̌ikić D (1963) Explanatory notes for basic geological mapsheet Rovinj. Institute for Geological Research, Zagreb

Prelogović E, Pribičević B, Ivković Ž, Dragičević I, Buljan R, Tomljenović B (2003) Recent structural fabric of the Dinarides and tectonically active zones important for petroleum-geological exploration in Croatia. Nafta 55(4):155-161 
Prelovšek P, Uran B (1984) Generalised hot wire method for thermal conductivity measurements. J Phys E Sci Instrum 17:674-677

Robertson EC (1988) Thermal properties of rocks. USGS, Reston

Rorabaugh MI (1953) Graphical and theoretical analysis of step-drawdown test of artesian wells, Separate 362. In: Transactions of the American Society of Civil Engineers, vol. 79, pp 1-23

Sass I, Burbaum U (2010) Damage to the historic town of Staufen (Germany) caused by geothermal drillings through anhydrite-bearing formations. Acta Carsologica 39:233-245

Šegota T (1982) Seawater level and vertical seabottom movement of the Adriatic Sea from the Riss-Würm interglacial until today. Geološki vjesnik 35:93-109

SIA (2010) Ground source heat pumps vol 384/6. Schweizer Ingenieurund Architektenverein, Zürich

Sokač B, Ščavničar B, Velić I (1967) Explanatory notes for basic geological map—sheet Gospić. Institute for Geological Research, Zagreb

Soldo V, Boban L, Borović S (2016) Vertical distribution of shallow ground thermal properties in different geological settings in Croatia. Renew Energy 99:1202-1212. https://doi.org/10.1016/j.renen e.2016.08.022

Stevanović Z, Milanović S, Ristić V (2010) Supportive methods for assessing effective porosity and regulating karst aquifers. Acta Carsologica 39:313-329

Surić M (2006) Late Pleistocene-Holocene palaeoenvironmental changes-records from submerged speleothems from the Eastern Adriatic Sea (Croatia). University of Zagreb

Terzić J, Šumanovac F, Buljan R (2007) An assessment of hydrogeological parameters on the karstic island of Dugi Otok, Croatia. J Hydrol 343:29-42. https://doi.org/10.1016/j.jhydrol.2007.06.008
Thiem A (1906) Hydrogeological methods. Gebhardt, Leipzig

Uran B (1982) Thermal conductivity measurement using hot wire method. University of Ljubljana, Ljubljana

Urumović KS (2000) Conditions of the seawater intrusions into karst aquifer of the Pula wells. Paper presented at the 2nd Croatian geological congress, Cavtat, 17-20 May 2000

Urumović K, Brkić Ž, Briški M (2013) Using automatic data loggers for well loss identification. Paper presented at the 5th consultations of the geologists of Bosnia and Herzegovina, Pale

Urumović K, Stroj A, Borović S (2016) Hydrogeological research for wells for heating and cooling of the hotel "Neptun 2". Croatian Geological Survey, Zagreb

VDI (2001) Thermal use of the underground, ground source heat pump systems. VDI, Düsseldorf

Velić I, Vlahović I (eds) (2009) Explanatory notes for the geological map of the Republic of Croatia 1:300,000. Croatian Geological Survey, Zagreb

Vlahović I, Tišljar J, Velić I, Matičec D (2005) Evolution of the Adriatic Carbonate Platform: palaeogeography, main events and depositional dynamic. Palaeogeogr Palaeoclimatol Palaeoecol 220:333-360

White WB (2002) Karst hydrology: recent developments and open questions. Eng Geol 65:85-105

Publisher's Note Springer Nature remains neutral with regard to jurisdictional claims in published maps and institutional affiliations. 